\title{
Archaeological Survey of a Portion of the Proposed Castroville Regional Park Improvement and Expansion, City of Castroville, Medina County, Texas
}

Richard B. Mahoney

Follow this and additional works at: https://scholarworks.sfasu.edu/ita

Part of the American Material Culture Commons, Archaeological Anthropology Commons, Environmental Studies Commons, Other American Studies Commons, Other Arts and Humanities Commons, Other History of Art, Architecture, and Archaeology Commons, and the United States History Commons

Tell us how this article helped you.

This Article is brought to you for free and open access by the Center for Regional Heritage Research at SFA ScholarWorks. It has been accepted for inclusion in Index of Texas Archaeology: Open Access Gray Literature from the Lone Star State by an authorized editor of SFA ScholarWorks. For more information, please contact cdsscholarworks@sfasu.edu. 


\section{Archaeological Survey of a Portion of the Proposed Castroville Regional Park Improvement and Expansion, City of Castroville, Medina County, Texas}

\section{Creative Commons License}

\section{(c) (1) (8)}

This work is licensed under a Creative Commons Attribution-NonCommercial 4.0 International License 


\section{Archaeological Survey of a Portion of the Proposed Castroville Regional Park Improvement and Expansion, City of Castroville, Medina County, Texas}

Richard B. Mahoney

Prepared for:

City of Castroville 1209 Fiorella Street Castroville, Texas

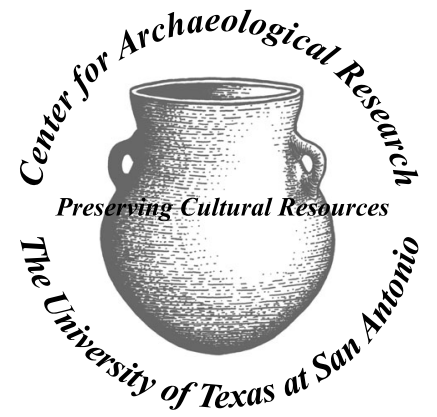

Prepared by:

Center for Archaeological Research The University of Texas at San Antonio Archaeological Survey Report, No. 347 


\title{
Archaeological Survey of a Portion of the Proposed Castroville Regional Park Improvement and Expansion, City of Castroville, Medina County, Texas
}

\author{
by
}

Richard B. Mahoney

Texas Antiquities Permit No. 3328

Steve A. Tomka

Principal Investigator

Prepared for:

City of Castroville 1209 Fiorella Street Castroville, Texas

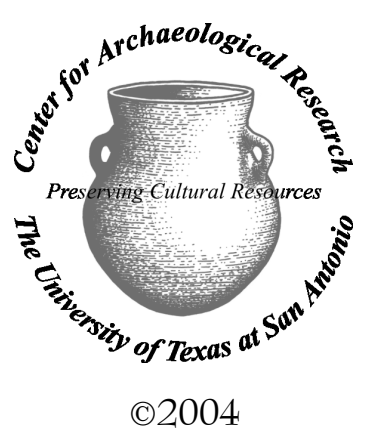

Prepared by:

Center for Archaeological Research The University of Texas at San Antonio Archaeological Survey Report, No. 347 
A list of publications offered by the Center for Archaeological Research is available. Call (210) 458-4378; write to the Center for Archaeological Research, The University of Texas at San Antonio, 6900 N. Loop 1604 W., San Antonio, Texas 78249-0658; e-mail to car@lonestar.utsa.edu; or visit CAR's web site at http://car.utsa.edu. 


\section{Abstract:}

During January 2004, the Center for Archaeological Research of The University of Texas at San Antonio conducted an archaeological survey of a selected portion (300 feet by 7 feet) of the proposed expansion and improvement of Castroville Regional Park in the City of Castroville, Medina County, Texas. The Phase I survey consisted of the excavation of six shovel tests. A single previously unrecorded prehistoric archaeological site (41ME134) was encountered atop a ridge landform. Abundant amounts of burned rock and lithic debitage, along with several tested cobbles, a few cores, and one non-diagnostic uniface were encountered at ground surface and within the upper $10 \mathrm{~cm}$ of shallow soils mantling the landform. Due to the primarily surficial nature of this site and the lack of cultural features, the Center for Archaeological Research recommends that site 41ME134 is ineligible for listing on the National Register of Historic Places or for designation as a State Archeological Landmark. It is therefore recommended that the proposed improvements proceed without further cultural resources investigations.

This work was conducted under Texas Antiquities Permit No. 3328 with Steve A. Tomka serving as Principal Investigator. Burned rock collected from the site was discarded pursuant to Chapter $26.27(\mathrm{~g})(2)$ of the Texas Administrative Code. All other artifacts collected during the survey are permanently housed at the Center for Archaeological Research curatorial facility. 


\section{Table of Contents:}

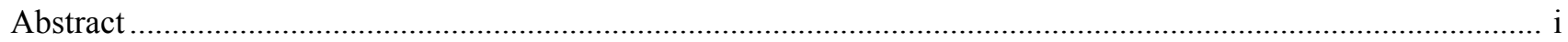

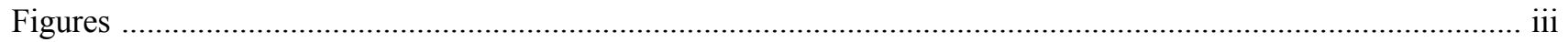

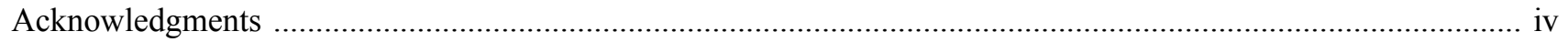

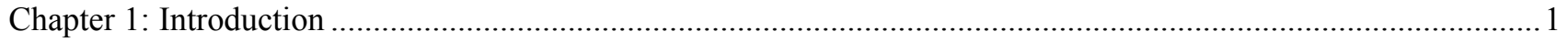

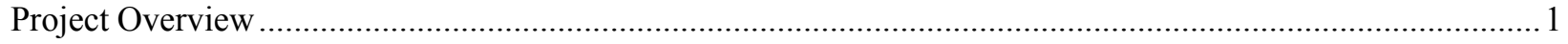

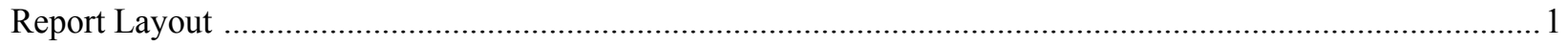

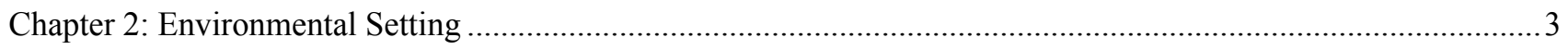

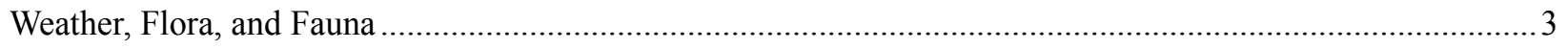

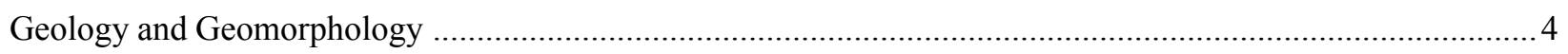

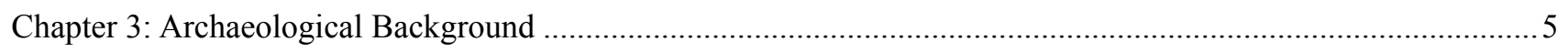

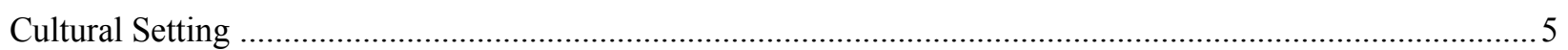

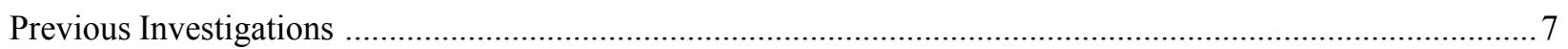

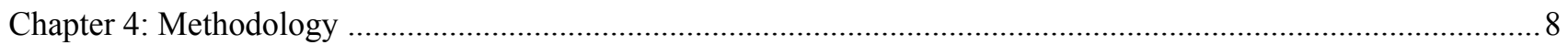

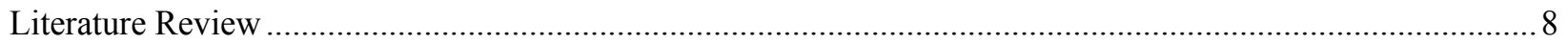

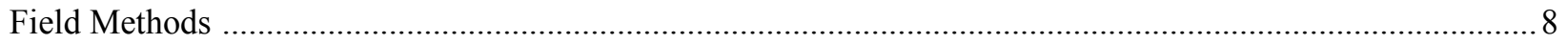

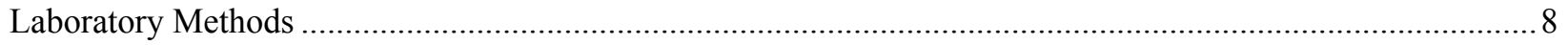

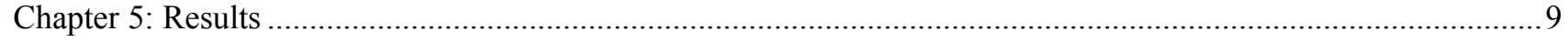

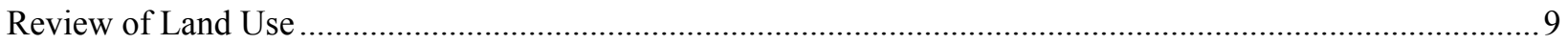

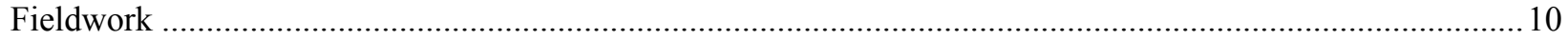

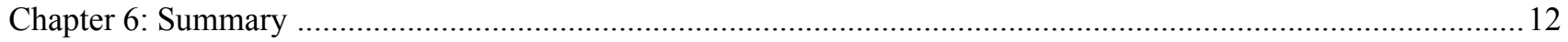

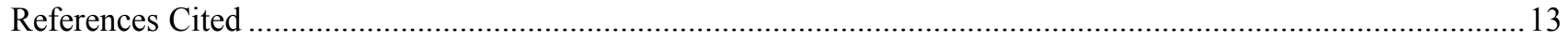




\section{Figures:}

Figure 1-1. Location of project area.

Figure 1-2. The location of Castroville Regional Park and the areas to be impacted by renovation efforts. .............2

Figure 2-1. Project area in relation to the vegetation regions of Texas. .................................................................. 3

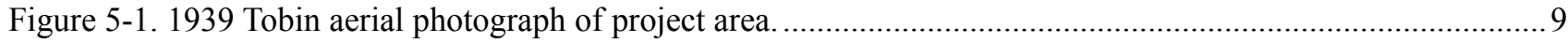

Figure 5-2. 1968 Tobin aerial photograph of project area. ........................................................................ 10

Figure 5-3. Sketch map of project area with shovel test locations and 41ME134 boundary. ................................ 11 


\section{Acknowledgments:}

Several individuals have contributed to the successful completion of this project. The Center for Archaeological Research (CAR) would like to thank Mr. Jack Yates and Mr. Ernie Ayala, City of Castroville, for facilitating CAR throughout the project. Mrs. Helen Delavan, member of the Regional Park Advisory Board, was also helpful with regard to scheduling the field efforts and providing the much-needed early aerial photographs. Andy Speer, under the direction of Marybeth Tomka, CAR Laboratory Director, conducted laboratory processing and inventory. Raymond P. Mauldin, CAR Associate Director, provided technical advice. Bruce Moses and Richard Young, CAR draftsmen, produced the figures in this report. Johanna Hunziker, CAR editor, produced the final version this report. 


\section{Chapter 1: Introduction}

The Center for Archaeological Research (CAR) of The University of Texas at San Antonio was contracted by the City of Castroville to conduct an archaeological survey of a selected portion of Castroville Regional Park which will be subject to park improvements and expansion. The park is located at 816 Alsace Street in the City of Castroville, Medina County, Texas (Figure 1-1). Subsurface disturbance in previously undisturbed areas will impact an area of approximately 300 linear feet. This area is in a proposed trail right-of-way which is seven feet wide, resulting in an area of roughly 2,100 square feet of impact to the undisturbed portion of the proposed trail. The purpose of the survey was to locate and identify any cultural resources that may be impacted by this proposed first stage of development. The survey was conducted by CAR staff during January 2004. In accordance with the Antiquities Code of Texas, the survey was performed under Texas Antiquities Permit Number 3328, with Steve A. Tomka, CAR Director, serving as Principal Investigator. undisturbed area in the current park bounds, and, as such, the likelihood for intact archaeological deposits within these significantly disturbed areas is minimal. As outlined in Chapter 5, proposed development items 1-5, listed previously, are wholly contained within these previously disturbed areas. Item 6 (development of a bird habitat and trail) also consists primarily of disturbed areas, although a small section (ca. 300 feet) of the seven-foot-wide construction right-of-way for the trail is apparently undisturbed. It is this area where CAR conducted the work summarized in this report.

\section{Report Layout}

This report is comprised of six chapters. Following this introductory chapter, Chapter 2 presents the environmental setting for the project area. Chapter 3 reviews the archaeological background for the area, including the cultural setting

\section{Project Overview}

The area of potential effect (APE) consists of (1) renovation of existing tennis courts; (2) renovation of an existing playground area; (3) installation of a sprinkler system; (4) construction of a pool pavilion; (5) construction of an interpretive trail; and (6) development of a bird habitat and trail (Figure 1-2). Each of these proposed activities will involve subsurface impact to the park area; however, only one of these is within a previously undisturbed area. During a review of the land-use history of Castroville Regional Park, it was discovered that significant alteration to the landscape has occurred in the recent past, as discussed in Chapter 5 . The southern portion of the park appears to have been used as a quarry as early as the 1930s. In addition, a series of artificial lakes and other invasive activities have occurred in the park. These activities left little

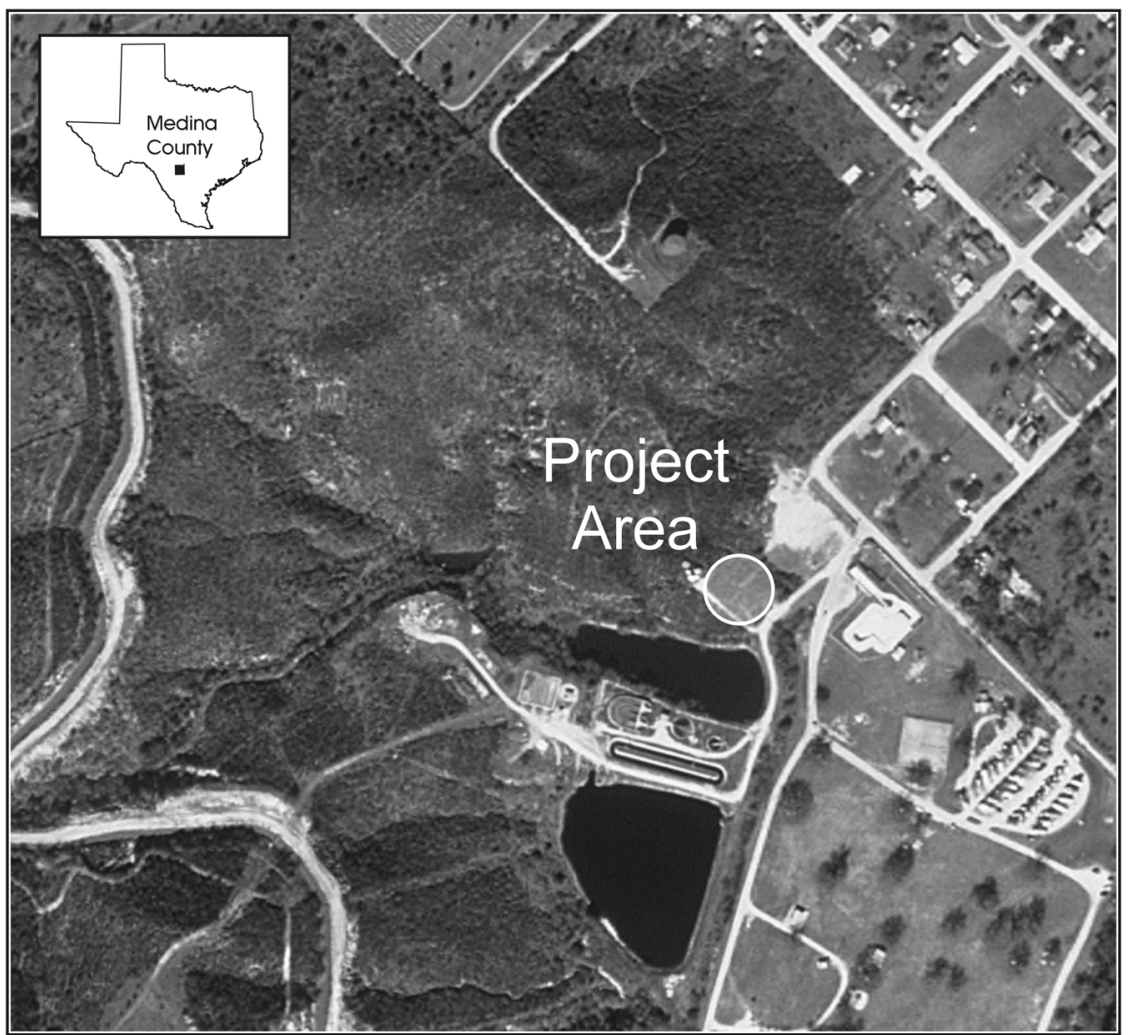

Figure 1-1. Location of project area. 
and previous archaeological investigations. Chapter 4 discusses the methodology employed, including the background literature review, field methods, and laboratory methods. Chapter 5 details the results of the archaeological fieldwork and laboratory processing. Chapter 6 summarizes the project and offers management recommendations.

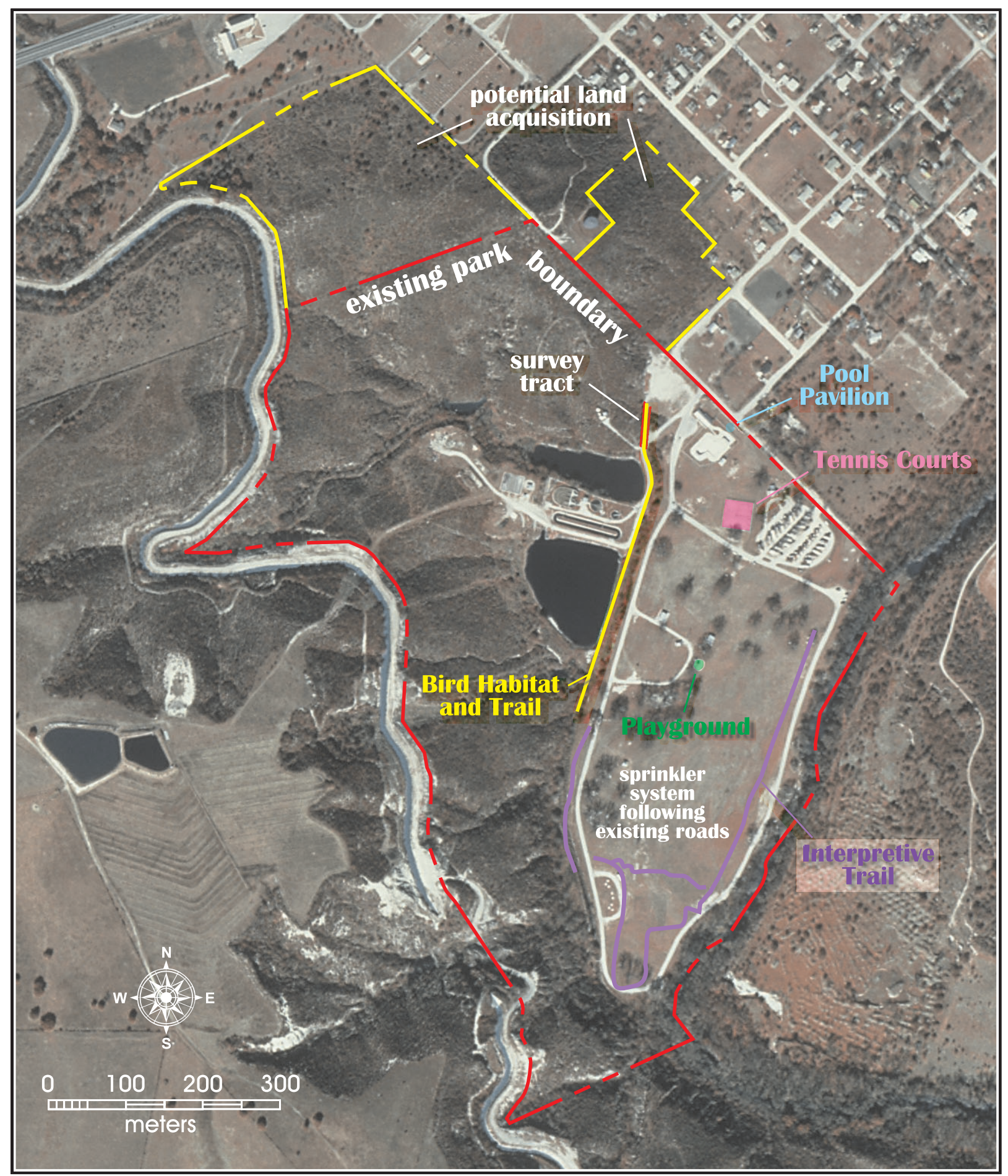

Figure 1-2. The location of Castroville Regional Park and the areas to be impacted by renovation efforts. 


\section{Chapter 2: Environmental Setting}

A summary of the environment specific to Medina County is provided as a background for understanding prehistoric human adaptations to the South Texas Brush Country, Blackland Prairie, and Edwards Plateau vegetation regions at this juncture (Figure 2-1).

The Medina River heads in the northwestern portion of Bandera County at the confluence of numerous streams draining the uplands of the Edwards Plateau. The perennial river follows a sinuous southeastern course across the Balcones Canyonlands, along which such cities as Medina, Bandera, and Castroville were settled. In 1912, the river was dammed along the political boundary of Bandera and Medina counties, forming Lake Medina.

\section{Weather, Flora, and Fauna}

Medina County has a subtropical climate, with relatively warm winters and hot summers. The mean daily minimum temperature during winter is $39^{\circ} \mathrm{F}\left(4^{\circ} \mathrm{C}\right)$ and the mean daily maximum temperature during summer is $98^{\circ} \mathrm{F}\left(37^{\circ} \mathrm{C}\right)$. The growing season averages around 263 days a year throughout the county (Dittmar et al. 1977). The prevailing winds alternate between a predominant northerly flow during the winter months to a predominant southeasterly flow during the summer months. The average annual precipitation is 28 inches $(72 \mathrm{~cm})$. Precipitation tends to be bimodal, with an initial peak occurring in May (mean $=3.67$ inches) and a secondary peak in September (mean=3.89 inches; Dittmar et al. 1977).

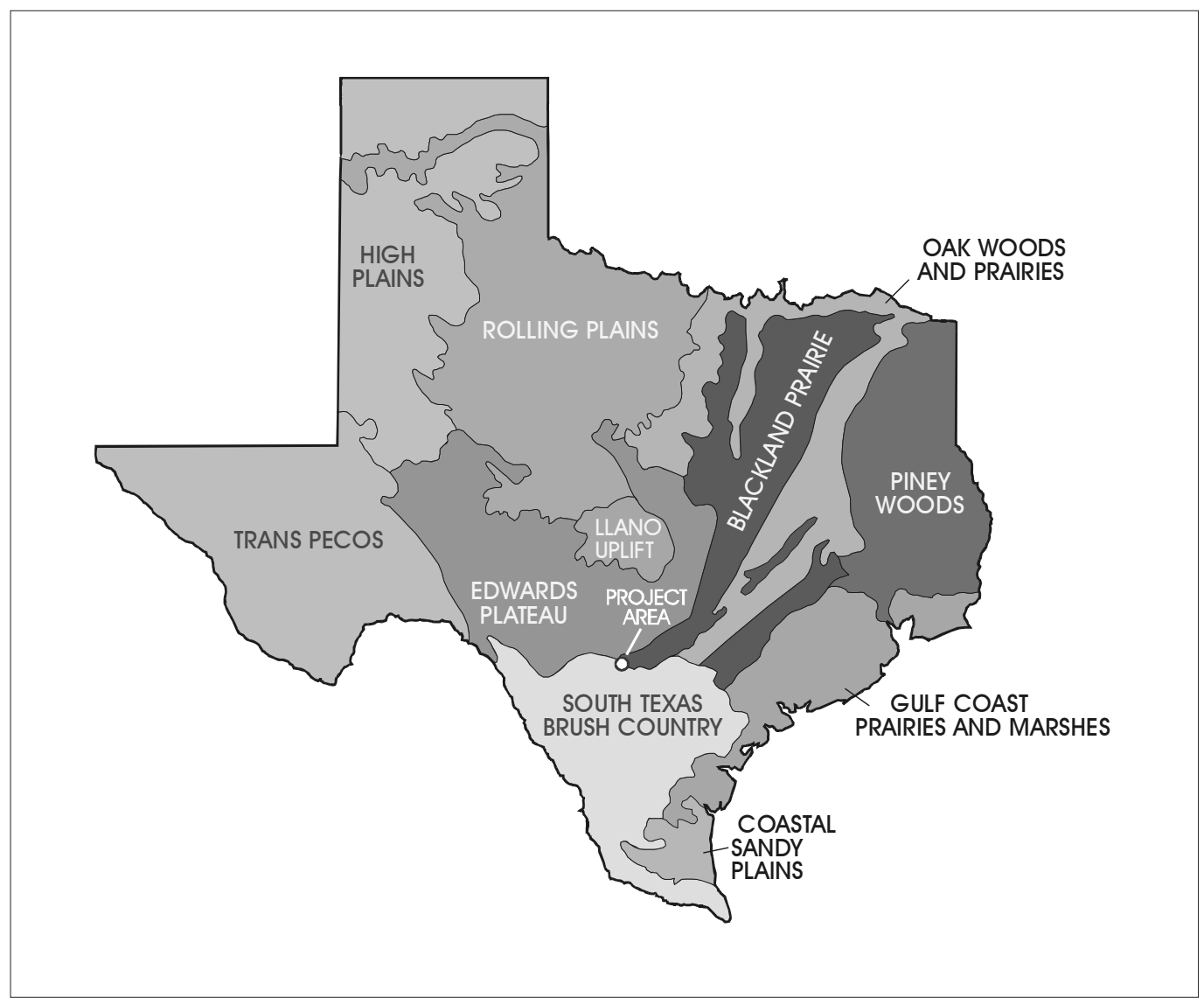

Figure 2-1. Project area in relation to the vegetation regions of Texas. Adapted from Texas Parks and Wildlife Department Natural Vegetation Regions of Texas map. 
The project area lies along the northern boundary of the Tamaulipan biotic region of South Texas, a region characterized by thorny brush including mesquite, acacia, white brush, and prickly pear (Blair 1950:103). The northern boundary of this region is formed by the Balcones Escarpment, or the southern terminus of Blair's (1950) Balconian biotic province.

Blair (1950:104) identifies the fauna of the region as diverse with numerous species of mammals, reptiles, and amphibians. Undeveloped areas, especially riparian zones along the Medina River, afford a resource-rich environment for such mammals as white-tailed deer, rabbit, squirrel, raccoon, opossum, skunk, and various rodents. Similarly, reptiles, amphibians, fish, and bivalves would favor such a riparian area.

\section{Geology and Geomorphology}

The geology of Medina County consists primarily of Mesozoic formations beginning with the Lower Cretaceous Glen Rose Limestone formation, which outcrops primarily in the northern portion of the county. Pleistocene and Holocene alluvial deposits are present along former stream channels south of the Balcones Escarpment. These geologically recent deposits are located primarily along Seco, Hondo, and Chacon creeks and Medina River. The project area sits atop a narrow strip of Upper Cretaceous Navarro Group Marl, flanking alluvial deposits of the Medina River (Bureau of Economic Geology 1982).

The project area is within the West Gulf Coastal Plain section of the Coastal Plains physiographic region (Fenneman 1931). The Kincheloe Series of clayey soils formed from eroded marls comprises the area of current investigations (Dittmar et al. 1977). Specifically, the soil is delineated as Kincheloe (KcF) soils, 10 to 30 percent slopes, with a clayey surface texture (Dittmar et al. 1977:Map Sheet 41). 


\section{Chapter 3: Archaeological Background}

A brief overview of the prehistoric cultural setting of South Texas relative to the project area and a synopsis of previous archaeological investigations conducted in the immediate vicinity of the project area are presented in this chapter. These summaries are based, in part, on more comprehensive reviews of cultural chronologies and archaeological investigations found in Black (1989), Hester (1995), Tomka et al. (1997), and Vierra (1998).

\section{Cultural Setting}

The chronological sequence discussed below is based on Black (1989), Collins (1995), and Hester (1995). It is intended to provide a relatively localized culture history of the project area. Most attempts to develop a culture history for South Texas have depended almost entirely on information from Central Texas, Lower Pecos, and Gulf Coast sites. This practice has been, in the past, considered acceptable because of the similarity of many artifact assemblages, especially projectile points, over most of South Texas. An additional contributing factor for the lack of a South Texas chronology may be due to the nature of the archaeological record in the region. Hester (1995:429) notes that most sites are open campsites, often found to be completely superficial or having very shallow artifactbearing zones which were either very stable over thousands of years or are the result of serious erosion and deflation. Many of these sites are "occupation zones," i.e., long, narrow stretches along creek or river banks with a thin scatter of artifacts containing a wide variety of temporal diagnostics in a confusing horizontal array. While the formation of such zones is, in itself, a distinctive regional trait, the analysis of material from such sites is difficult (Hester 1995:430). The lack of buried, undisturbed, stratified sites in the region has severely limited the development of a regional chronology.

\section{Paleoindian (1 1,200-8000 BP)}

The early Paleoindian period, characterized by Clovis and Folsom point types, is not well understood throughout South Texas. An early Paleoindian presence in South Texas is represented by rare finds of Clovis and Folsom points (Hall 1984; Hester 1995). Bifacial Clear Fork tools and finely flaked end scrapers are often associated with Paleoindian points (Black 1989). Many of these early Paleoindian points are found as isolated artifacts or in association with later materials (Hall 1984).
Paleoindian groups are assumed to have been small and highly mobile, focusing primarily on the exploitation of large game. However, recent research on Paleoindian materials from the Wilson-Leonard site in Central Texas (Collins 1998), and new perspectives on Paleoindian adaptations (e.g., Tankersley and Isaac 1990) suggest that the diet of these early groups may have been much broader than previously assumed. A variety of small game may have served as common sources of animal protein, at least on a seasonal basis. Similarly, the distance traveled by a group may have been, at least in some cases, much smaller than previously assumed (Tankersley and Isaac 1990).

While isolated Paleoindian projectile points are found on a variety of landforms (Hester 1995), most sites with Paleoindian materials are found on high terraces, valley margins, and upland locations (Black 1989). This pattern is similar to Paleoindian site distribution in other parts of the country in that sites of this time period tend to be found on landforms that provide good overviews of the surrounding landscape, are centered on critical resource zones, or are found in high-productivity drainage areas (Tankersley and Isaac 1990). The existence of deeply buried Paleoindian components in alluvial contexts (Berger Bluff [41GD40]; Brown 1987) does indicate that some caution should be exercised in excluding valley bottom settings from the Paleoindian land-use system.

\section{Early Archaic (8000-5000 BP)}

Sollberger and Hester (1972) have suggested that the shift from the Paleoindian to the Archaic tradition was gradual, and spanned nearly 3,000 years $(8000-5500 \mathrm{BP})$ in central and southern Texas. Hester (1995:436), using only projectile point morphology, defined two widespread horizons for the Rio Grande Plains. These are the Early Corner-Notched (8000-5500 BP) marked by Uvalde, Martindale, and Baker point forms; and the Early Basal-Notched (5500-5000 BP) characterized by Bell and Andice points. He believes that the distinctive Guadalupe biface may be associated with the former.

Early Archaic sites are usually found on terraces near water or on hilly areas overlooking valleys (Hester 1995:439). Both in the Chaparrosa Ranch and East Chacon areas of western South Texas, Early Archaic sites tend to be found in "water-proximate" areas, such as high terraces 
overlooking major creeks (see Hester 1978; McGraw and Knepper 1983). Almost no direct evidence of subsistence is available, largely because the preservation of faunal material and plant macro- and micro-remains is poor in the Rio Grande Plains (Hester 1995:439).

\section{Middle Archaic (5000-2400 BP)}

Diagnostic artifacts for this period include Pedernales, Langtry, Kinney, and Bulverde point types. Tortugas, Morhiss, and Lange point types appear late in the period, after 2950 BP. (Black 1989). In addition, distally beveled tools, tubular pipes, and triangular bifaces, which persist throughout the Archaic, are common (Black 1989; Hester 1995). Although not as numerous or as large as those found in Central Texas, accumulations of burned rock containing artifacts datable to this interval are found in the northern parts of South Texas. Manos and metates are common from this period and into the Late Archaic. In general, the evidence points to less intensification of vegetal resource utilization than is seen in Central Texas.

During the Middle Archaic, open campsites occur inland on knolls and bluffs along stream channels and tributaries, and along estuary bays in the Coastal Bend region (Black 1989; Story 1985). In the later Middle Archaic period, sites are also commonly located on floodplains, low terraces, and natural levees, in addition to the upland settings (Hester 1995).

Subsistence remains from Middle Archaic sites indicate the use of nuts and mesquite beans, acacia, hackberry, and oak (Hall et al. 1986). Freshwater mussels, land snails, deer, and small mammal remains are common, as are littoral resources along the coast (Black 1989).

The first large cemeteries appear during the later part of the Middle Archaic, at sites like Loma Sandia (Taylor and Highley 1995) and Morhiss (Campbell 1976). It has been suggested that these cemeteries reflect an increase in population and/or territorial restriction (Black 1989; Hester 1995; Story 1985).

\section{Late Archaic (ca. 2400-1150 BP)}

The Late Archaic in South Texas is characterized by the presence of Shumla, Ensor, Montell, and Marcos point types and Olmos bifaces (Hester 1995:441). In and near Webb County, Desmuke, Matamoros, and Catan points are found. Large (15-20 cm long), thin, triangular bifaces made of nonlocal cherts are another Late Archaic tool found in the Rio Grande Plains area (Hester 1995:442). Corner-tang bifaces and small distally beveled tools called Nueces scrapers are common (Black 1989). Olmos bifaces, small triangular gouge-like tools, are common in South Texas (Hester 1995). Manos and grinding slabs also are common in South Texas.

Late Archaic sites are usually located near modern stream channels and occur in all topographic settings (Black 1989; Hester 1995). Sloughs or oxbow lake margins were also preferred site locations (Kelly 1983; McGraw and Knepper 1983). Subsistence was broadly based, with a wide range of animal bone present in sites, along with large amounts of freshwater mussel shell in some sites (Hester 1995:442). There seems to have been a greater reliance on a broad spectrum of plant resources, with small animals (e.g., rodents, rabbits, turtles, fish, lizards, and snakes) and land snails also of importance (Black 1989).

Throughout the Late Archaic there is a continued use of large cemeteries first seen in the Middle Archaic. Examples include the Ernest Witte, Leonard K., and Morhiss sites, as well as many others (Perttula 1997; Taylor and Highley 1995). There is an increase in the number and variety of grave inclusions found in the later Archaic burials at these cemeteries (Black 1989; Hall 1981, 1984; Hester 1995).

\section{Late Prehistoric (ca. 1150-350 BP)}

At about 1150 BP there is a distinctive shift in artifact assemblages across Central and South Texas: the use of the atlatl and dart points is replaced by the bow and arrow. This change is not apparent along the coastal regions until about 750 BP. This early period of the Late Prehistoric in Central Texas is termed the Austin Phase (1150-600 BP). During this period, the first evidence of bone-tempered pottery is found in association with expanding stem arrow points. Edwards, Granbury, and Scallorn arrow points are commonly found on early Late Prehistoric sites; the latter type, in particular, is found over most of the state. Edwards points have been found largely in the Rio Grande Plains, although they are occasionally seen outside this area (Prewitt 1995:102). The relationship of this point to Scallorn points and other Austin Phase arrow points is still being addressed (Hester 1995:443).

At about 600 BP there is another distinct change in lithic tool assemblages: arrow point forms shift from expanding stem types to contracting stem types such as Perdiz and Cliffton (Black 1989). This latter part of the Late Prehistoric in Central and South Texas is termed the Toyah Phase. It is characterized by Perdiz and Cliffton arrow points, often 
found in association with bison bones or kill sites, beveled bifaces, drills, small scrapers, a flake-blade lithic technology, and bone-tempered Leon Plain ceramics (Hall 1981; Prewitt 1981; Skelton 1977). Tools made from bison bone also are common. A sharp increase in the frequency of bison bone in Toyah sites suggests that the importance of hunting of large game increased, though small mammals, riverine species, mussels, and land snails continued to be important contributions to the diet (Hall 1981; Hester and Hill 1975; Prewitt 1981; Skelton 1977).

\section{Previous Investigations}

To summarize the range of previously recorded archaeological sites and archaeological investigations in Medina County, the Texas Archeological Sites Atlas (Texas Historical Commission [THC] 2004) was consulted in January 2004. At that time, only 122 archaeological sites had been recorded in the county. The majority of these sites occur along the Medina River in the eastern portion of the county. Other loci of recorded sites include West Verde Creek in the northern portion of the county, the area surrounding the city of D'Hanis (e.g., Frkuska and Frkuska 1982) in the western portion of the county, and the area surrounding the city of Devine (e.g., Jurgens 1989) in the southeastern portion of the county.

Professional archaeological excavations within the current political bounds of Medina County have been limited. As of January 2004, only 40 cultural resources report abstracts are indicated in the Texas Archeological Sites Atlas (THC 2004). Roughly half of these previous investigations concern studies connected with roadway development. The majority of the remainder of investigations address cultural resources associated with waterways. Other, site-specific, studies such as investigations at the Landmark Inn in Castroville (Parsons and Burnett 1984) comprise the balance of previous archaeological investigations in the county. 


\section{Chapter 4: Methodology}

This chapter details the various field and laboratory techniques and methods used to investigate the project area. Each general step of the process is presented and includes sections concerning the initial literature review, field methods, and laboratory methods.

\section{Literature Review}

The archaeological research commenced with a comprehensive review of all available archaeological reports and databases to identify and characterize all archaeological sites known to occur in the vicinity of the project area. At least in part, the compilation of the known prehistoric and historic sites within and in the vicinity of the project area is based on the Texas Archeological Sites Atlas, Texas Historic Sites Atlas, and THC map files. The literature and archival review also inspected United States Geological Survey (USGS) topographic maps and the USDA Soil Conservation Service's Soil Survey of Medina County (Dittmar et al. 1977). In addition, with the enthusiastic help of Mrs. Helen Delavan, recent project-specific aerial photographs were assembled to define the precise limits of the project area.

\section{Field Methods}

The survey consisted of a 100 percent pedestrian survey of the proposed bird habitat and trail area (300 linear feet). A crew of one archaeologist traversed the project area along the centerline of the proposed trail. Aerial photographs with clearly marked transects and a hand-held compass were used to orient the survey route.

For the purpose of this survey, sites were defined as locations having at least five artifacts within a $30 \mathrm{~m}^{2}$ area, or as a location containing a single cultural feature such as a hearth. All other artifacts were classified as isolated occurrences. Shovel tests were conducted in accordance with the Texas Historical Commission Minimum Survey Standards for Linear Projects, which specify a shovel test density of 16 shovel tests for every one (1) linear mile.

Shovel tests were $30 \mathrm{~cm}$ in diameter and were excavated to a maximum depth of $50 \mathrm{~cm}$ below surface, unless otherwise prevented from reaching this depth. They were excavated in levels not exceeding $10 \mathrm{~cm}$ in thickness. Deposits from these tests were screened through $1 / 4$-inch hardware cloth, all artifacts were collected, and observations on the shovel tests were recorded on standardized forms.

\section{Laboratory Methods}

All cultural materials recovered were inventoried at the CAR laboratory. All artifacts recovered were identified and analyzed. Processing of recovered artifacts began with washing and sorting into appropriate categories (e.g., debitage, tools). The catalog was entered into an Excel spreadsheet.

All cultural material collected during the survey was prepared in accordance with current state and/or federal regulations. Artifacts processed in the CAR laboratory were stored in archival-quality bags. Acid-free labels were placed in all artifact bags. Each label contains a provenience or corresponding lot number.

Subsequent to proper analyses and/or quantification, artifacts possessing little scientific value were discarded pursuant to Chapter 26.27(g)(2) of the Texas Administrative Code. Artifact classes discarded specific to this project included burned rock. In all instances discarded materials were documented and their counts included in this report and curation documentation. Discarded materials were disposed of in a manner consistent with suitable disposal procedures.

Field notes, forms, and drawings were placed in archivally stable folders. All folders were stored in file cabinets. Documents and forms were printed on acid-free paper. A copy of the survey report and all computer disks pertaining to the investigations are curated with the field notes and documents. After completion of the project, all cultural material and records were curated at the CAR permanent storage facility. 


\section{Chapter 5: Results}

This chapter presents the results of investigations for the Castroville Regional Park project. Similar to the previous chapter on methodology, this chapter is subdivided into sections reporting on the results of the initial land-use review and the fieldwork.

\section{Review of Land Use}

Numerous cartographic resources were examined to determine the extent of historic activity within the area. A 1939 Tobin aerial photograph of the project area (Figure 5-1) depicts probable quarrying in that region. By 1968 , quarrying operations had expanded to include the majority of the park along the right-descending bankline of the Medina River (Figure 5-2). Also by 1968, an artificial lake with associated dam had been constructed in the western portion of the project area. Visible in the 1968 aerial photograph is an area of unknown activity to the northeast of the artificial lake wherein significant disturbance is apparent. Sometime after this later aerial photograph was taken, a second artificial lake was dammed south of the existing lake (see Figure 1-2). In review of Figures 5-1 and 5-2, it is apparent that the Medina River once followed a meander west of its current channel. This likely former meander probably once cut through the middle of the current project APE. The line of trees that is visible in Figure 5-2 occurs along a filled channel that crosses the center of the park.

Development item 1 (renovation of existing tennis courts) occurs in areas previously disturbed by construction of the original tennis courts. Item 2 (renovation of an existing playground) will impact areas previously disturbed by construction of the original playground. Item 3 (installation of a sprinkler system) will occur within the existing park roads, an area previously impacted by the quarrying activities. Item 4 (installation of a pool pavilion) occurs within the disturbed area northeast of the northern artificial lake. Item 5 (construction of an interpretive trail) occurs within the extensive quarry area in the southern portion of the park. Item 6 (development of a bird habitat and trail) consists primarily of disturbed areas. Particularly, the proposed bird habitat trail heads along an existing paved sidewalk in the southwestern portion of the park, follows the top of the artificial dam, continues along an existing unpaved road, and terminates in the disturbed area noted in the northwestern portion of the park. Nevertheless, a small portion (ca. 300 linear feet) of the trail traverses an apparently undisturbed tract (see Figure 1-2). It is this small, undisturbed portion of the proposed project area that is the sole subject of the archaeological field investigations. The proposed trail right-of-way is seven feet wide, and its construction will require vegetation clearance and the spreading of a three-inch-thick caliche base.

The results of the land-use review have obviated the need for a cultural resources survey for the majority of the currently proposed developments due to substantial, previous disturbances. Only that portion of the proposed trail alignment that traverses an area of roughly 300 linear feet in the northwestern portion of the park crosses previously undisturbed ground.

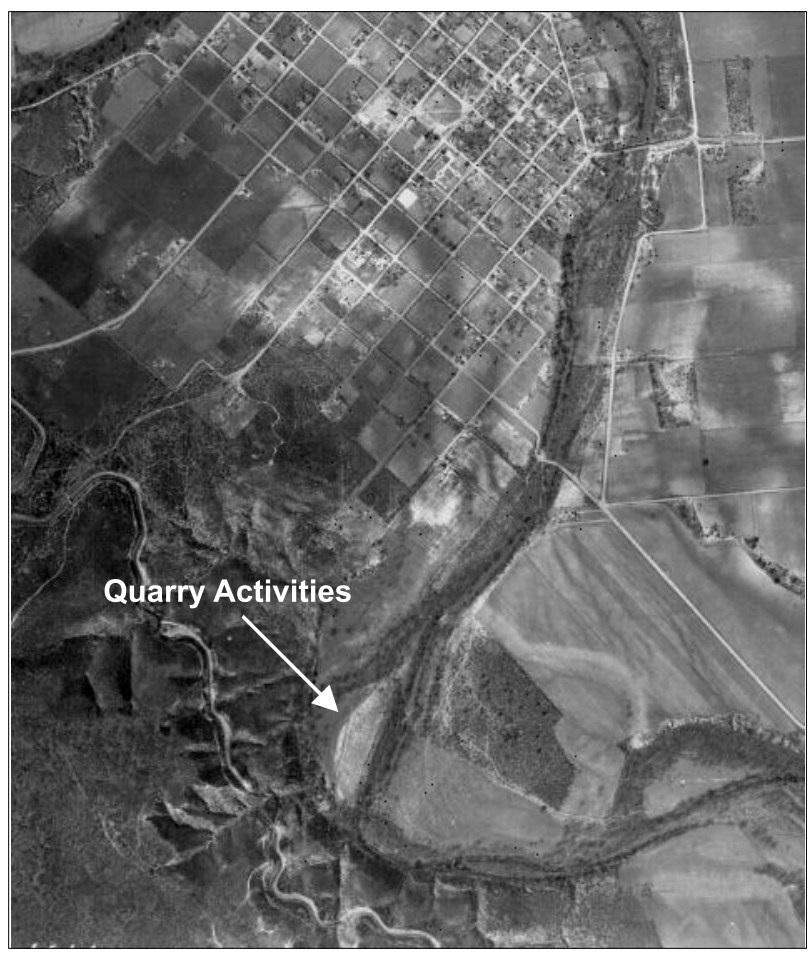

Figure 5-1. 1939 Tobin aerial photograph of project area. 


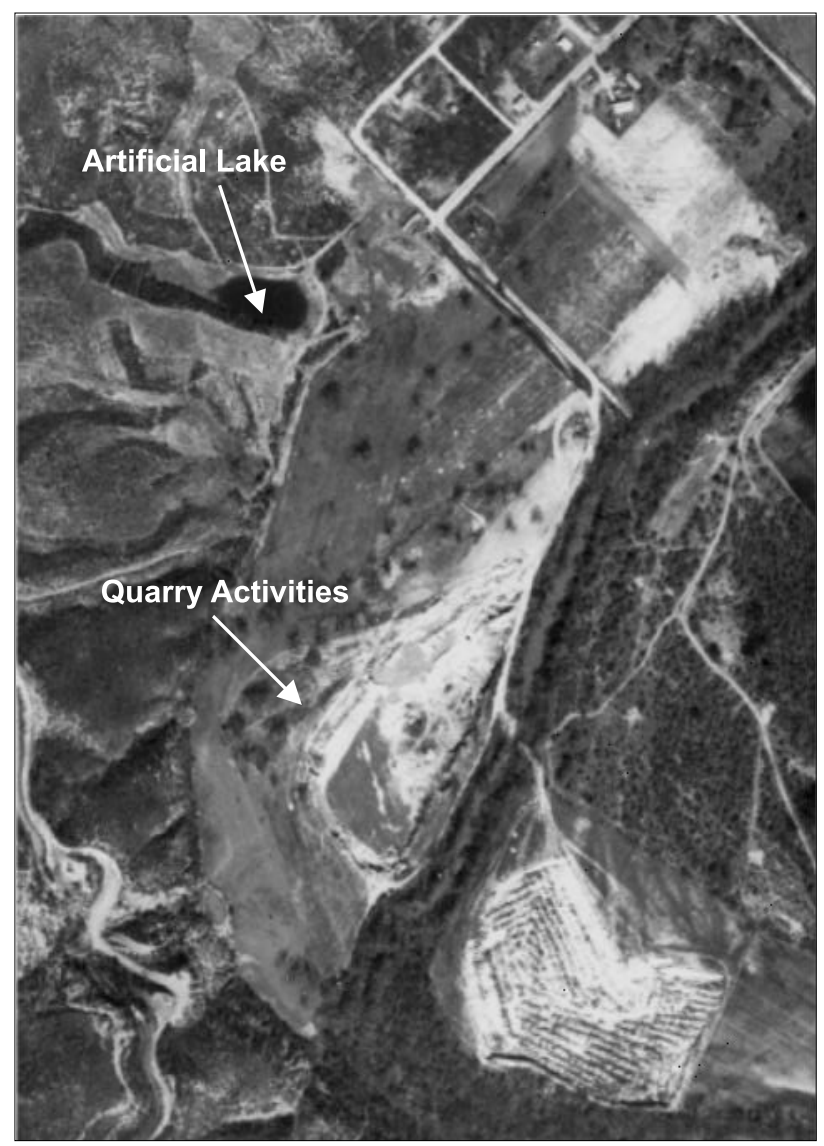

Figure 5-2. 1968 Tobin aerial photograph of project area.

\section{Fieldwork}

The surface survey identified a scatter of lithic debitage, cores, and burned rock within the undisturbed portion of the proposed bird habitat trail right-of-way. The undisturbed portion of the trail right-of-way traverses the tip of a finger ridge (see Figure 1-2) and slopes toward the southeast. Given that no cultural materials were noted along much of the previously undisturbed right-of-way, and since any subsurface deposits would have been in a secondary colluvial matrix, only one shovel test was excavated along the rightof-way proper. The single shovel test was excavated at the extreme southern end of the undisturbed right-of-way where prehistoric materials were noted on surface. When this shovel test (ST-R6 in Figure 5-3) produced no buried materials, the field archaeologist sought to discover the source of the cultural materials. A brief survey upslope, northwest of the right-of-way, identified a scatter of prehistoric cultural materials distributed along the crest of the ridge. It was felt that this exploration outside of the rightof-way was warranted since cultural materials adjacent to public access trails could be subject to secondary impacts (i.e., artifact collecting) due to their high visibility. A total of six shovel tests was excavated in and near the selected portion of the project area (Figure 5-3).

A single archaeological site (41ME134) was encountered and recorded during the field efforts. The site occurs along the top of the ridge, extending from the paved dam road northwest to the abandoned radio tower (see Figure 5-3). Only a small portion of the site extends into the undisturbed portion of the proposed trail right-of-way and this portion appears to be devoid of buried cultural materials as indicated by the negative shovel test (ST-R6). The ridge crest slopes from 790 feet AMSL in the western portion of the site to an abrupt 770 feet AMSL in the eastern portion of the site. The paved dam road has likely obliterated the extreme eastern portion of the site, as a sharp elevational drop-off of nearly 10 feet occurs at the juncture of the road and the site.

Vegetation within the site bounds consists of dense brush and scrub comprised primarily of mesquite, yucca, and prickly pear cactus. While this dense vegetation hampered survey efforts, ground surface visibility was fair at roughly 50 percent. Burned rock, lithic debitage, tested cobbles, and cores occur along the surface of the ridge top, with colluvial redeposition of materials downslope along game trails. Erosion and animal activity is evident in the redeposition of the materials downslope. The site, as expressed atop the ridge, covers an area approximately $60 \mathrm{~m}$ long and $10 \mathrm{~m}$ wide or $600 \mathrm{~m}^{2}$.

Soils encountered in the shovel tests varied in depth from $2-50 \mathrm{~cm}$ below surface (cmbs) and consisted primarily of silty clays. Abundant chert and limestone gravels, cobbles, and nodules occur at ground surface and their relative densities dictated the depth of excavation of all but one shovel test. Five of the six shovel tests failed to extend below $10 \mathrm{cmbs}$ due to the density of rock encountered. The single exception was ST-R4, wherein dense, impenetrable marl halted excavation at $50 \mathrm{cmbs}$.

Of the six shovel tests, only two (ST-R1 and ST-R2) encountered buried artifacts, with a total recovery of seven pieces of burned rock. The burned rocks consist of six heat spalls and a single heat spalled chert pebble. It is likely that the heated materials are the product of brush fires rather than cooking with heated rocks, given that the single pebble 
is small and six of the seven pieces are spalls rather than heat-fractured rocks. However, given the presence of numerous chert flakes on the surface of the site, there is a slight possibility that the heat spalls may also be prehistoric in origin. All seven of the buried specimens come from Level $1(0-10 \mathrm{cmbs})$. In addition, although numerous burned rocks occurred along the ridge crest, no intact burned rock features (i.e., hearths) were encountered during the survey. Again, it is possible and indeed likely that some if not all of the burned rock is the product of surface fires rather than prehistoric food processing activities. Nonetheless, the presence of tool manufacture debitage does indicate that some prehistoric human activity has occurred on the ridge forming the low density site identified by this survey.
Evidence of previous disturbance within the site bounds appears minimal. Aside from the probable extreme eastern portion of the site impacted by the paved dam road, mentioned previously, no extensive disturbance is evident. An overhead utility line pole has been placed near the center of the site, although disturbance from its installation appears minimal.

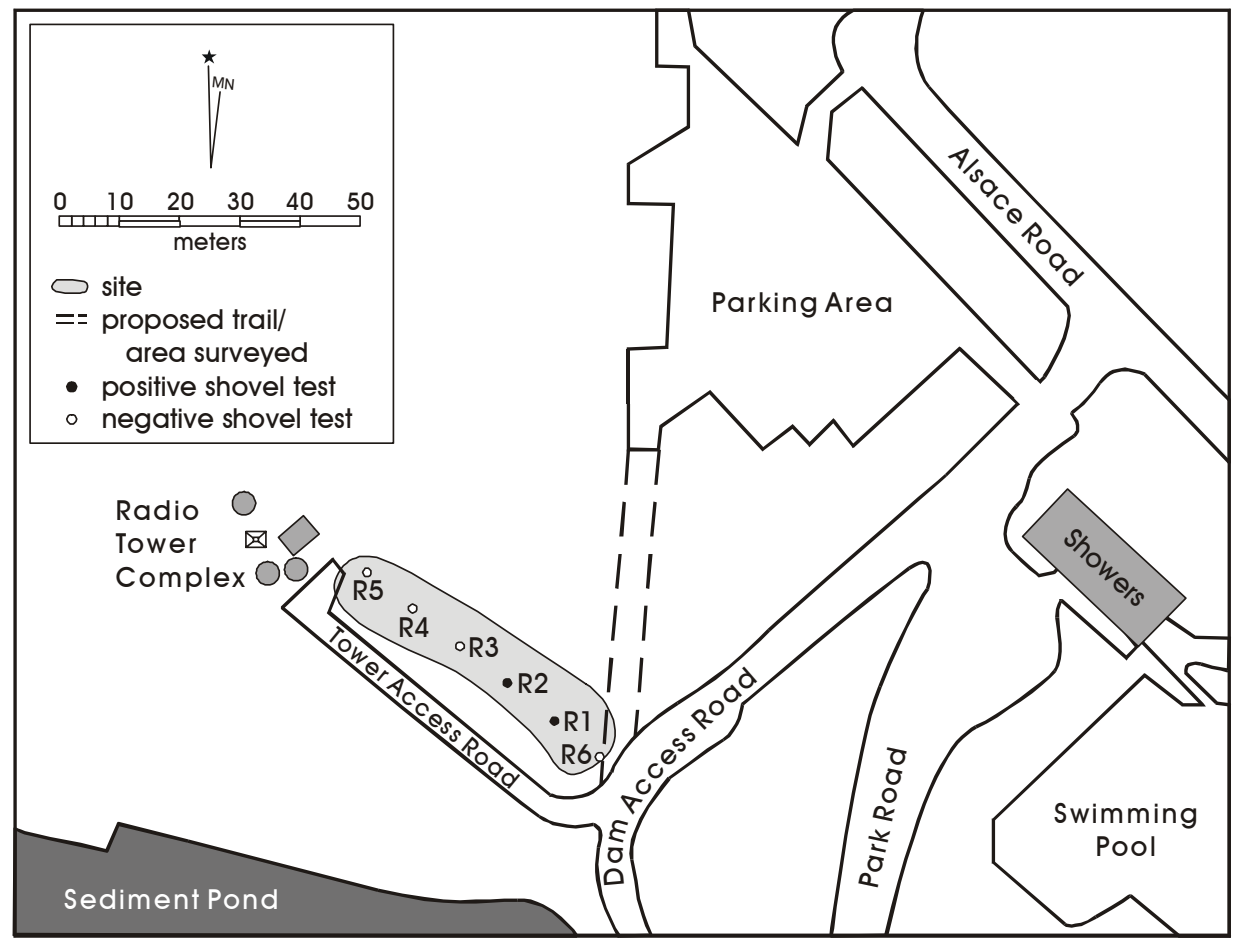

Figure 5-3. Sketch map of project area with shovel test locations and 41ME134 boundary. 


\section{Chapter 6: Summary}

The Center for Archaeological Research was contracted by the City of Castroville to perform Phase I survey to identify cultural resources that may be impacted by proposed park improvements. The proposed park improvements consist of (1) renovation of existing tennis courts; (2) renovation of an existing playground area; (3) installation of a sprinkler system; (4) construction of a pool pavilion; (5) construction of an interpretive trail; and (6) development of a bird habitat and trail.

The renovation of existing facilities (items 1, 2, and 4) involved disturbances only to previously impacted areas and, therefore, in the scope of work accompanying the permit application CAR proposed that these areas needed no archaeological survey. Similarly, the construction of the sprinkler system will occur inside existing roads and will disturb only previously impacted areas. The planned interpretive trail also is to be constructed within the former quarry area. Because this area was heavily disturbed, CAR recommended no survey in this area. Finally, review of the land-use history within the current boundaries of the park indicates that the proposed bird habitat and trail traverses primarily disturbed landforms. Nonetheless, a small portion, measuring approximately 300 feet in length, was identified as the only previously undisturbed area within the APE of the proposed trail. The remainder of the proposed trail follows areas previously subjected to extensive subsurface impacts such as existing dirt and paved roads and artificially dammed lakes.

A single, previously unrecorded prehistoric site (41ME134) was discovered atop a ridge extending into and in the immediate vicinity of the survey area. This site contains lithic debitage, burned rock, tested cobbles, cores, and a single non-diagnostic uniface found on the surface. Six shovel tests were excavated to a terminal depth of $2-50 \mathrm{cmbs}$. Cultural material was only encountered in the upper $10 \mathrm{~cm}$ of soil in two of the test units. The surficial nature of the site, coupled with the lack of any features or temporally diagnostic artifacts, suggests that $41 \mathrm{ME} 134$ possesses little or no research potential.

In conclusion, the current archaeological survey has defined the location of a prehistoric site of unknown temporal affiliation. Although the survey encountered abundant burned rock, some if not the majority of the burned rock may have been produced by brush fires rather than prehistoric food processing activities (i.e., rock-lined hearths). Excavation of six shovel tests has revealed that the extent of cultural material does not extend below $10 \mathrm{~cm}$ below surface. It is evident that the site is expressed primarily in a surficial context and lacks depositional integrity. While additional archaeological investigations may encounter temporally diagnostic material, it is unlikely that significant cultural features are extant due to the shallow nature of the soils atop the ridge.

It is therefore the recommendation of the Center for Archaeological Research that site 41ME134 is neither eligible for listing on the National Register of Historic Places nor designation as a State Archeological Landmark. As such, no further cultural resources investigations are recommended for this portion of the Castroville Regional Park and development should be allowed to proceed as planned. 


\section{References Cited}

Black, S. L.

1989 Central Texas Plateau Prairie. In From the Gulf Coast to the Rio Grande: Human Adaptation in Central, South and Lower Pecos Texas, by T. R. Hester, S. L. Black, D. G. Steele, B. W. Olive, A. A. Fox, K. J. Reinhard, and L. C. Bement, pp. 17-38. Research Series No. 33. Arkansas Archeological Survey, Fayetteville.

Blair, W. F.

1950 The Biotic Provinces of Texas. Texas Journal of Science 2(1):93-117.

Brown, K. M.

1987 Early Occupation at Berger Bluff, Goliad County, Texas. Current Research in the Pleistocene 4:3-5.

Bureau of Economic Geology

1982 Geologic Atlas of Texas: San Antonio Sheet. Bureau of Economic Geology. The University of Texas at Austin.

Campbell, T. N.

1976 Archaeological Investigations at the Morhiss Site, Victoria County, Texas, 1932-1940. In An Archaeological Survey of Coleto Creek, Victoria and Goliad Counties, Texas, by A. A. Fox and T. R. Hester, pp. 81-85. Archaeological Survey Report, No. 18. Center for Archaeological Research, The University of Texas at San Antonio.

Collins, M. B.

1995 Forty Years of Archeology in Texas. Bulletin of the Texas Archeological Society 66:361-400.

1998 Wilson-Leonard: An 11,000-year Archeological Record of Hunter-Gatherers in Central Texas. Studies in Archeology, Report No. 31. Texas Archeological Research Laboratory, The University of Texas at Austin. Archeology Studies Program, Report No. 10. Environmental Affairs Division, Texas Department of Transportation, Austin.

Dittmar, G. W., M. L. Deike, and D. L. Richmond

1977 Soil Survey of Medina County, Texas. United States Department of Agriculture, Soil Conservation Service, Washington, D.C.

Fenneman, N.

1931 Physiography of the Western United States. McGraw Hill, New York.

Frkuska, A., Jr., and E. G. Frkuska

1982 A Cultural Resource Survey for Medina Electric Cooperative, Inc., in Uvalde, Medina, and Frio Counties, Texas. Archaeological Survey Report, No. 117. Center for Archaeological Research, The University of Texas at San Antonio.

Hall, G. D.

1981 Allens Creek: A Study in the Cultural Prehistory of the Brazos River Valley, Texas. Research Report 61. Texas Archeological Survey, The University of Texas at Austin.

1984 Archaeology of the Texas Central Coastal Plain. Unpublished manuscript on file Center for Archaeological Research, The University of Texas at San Antonio. 
Hall, G. D., T. R. Hester, and S. L. Black (editors)

1986 The Prehistoric Sites at Choke Canyon Reservoir, Southern Texas: Results of the Phase II Archaeological Investigations. Choke Canyon Series, No. 10. Center for Archaeological Research, The University of Texas at San Antonio.

Hester, T. R.

1978 Background to the Archaeology of Chaparrosa Ranch, Southern Texas. Volume I: Studies in the Archaeology of Chaparrosa Ranch. Special Report, No. 6. Center for Archaeological Research, The University of Texas at San Antonio.

1995 The Prehistory of South Texas. Bulletin of the Texas Archeological Society 66:427-459.

Hester, T. R., and T. C. Hill

1975 Some Aspects of Late Prehistoric and Protohistoric Archaeology in Southern Texas. Special Report, No. 1. Center for Archaeological Research, The University of Texas at San Antonio.

Jurgens, C. J.

1989 Archeological Survey of Proposed Wastewater System Improvements at the City of Devine, Medina County, Texas. Texas Water Development Board, Austin.

Kelly, R. L.

1983 Hunter-Gatherer Mobility Strategies. Journal of Anthropological Research 39:277-306.

McGraw, A. J., and D. Knepper

1983 The East Chacon Project: 11,000 Years of Prehistory along the Upper Nueces River, Southern Texas. Archaeological Survey Report, No. 125. Center for Archaeological Research, The University of Texas at San Antonio.

Parsons, M., and R. E. Burnett

1984 Landmark Inn State Historic Site: Archeological Investigations 1975-1980, Medina County, Texas. Texas Parks and Wildlife Department, Austin.

Perttula, T. K.

1997 Hunter-Gatherer Mortuary Practices. In Archaeology of the Rio Grande and Central Coastal Plains, Texas: A Planning Document, pp. 7.1-7.51, edited by S. A. Tomka, T. K. Perttula, and R. J. Hard. Archaeological Survey Report, No. 266 (Draft). Manuscript on file Center for Archaeological Research, The University of Texas at San Antonio.

Prewitt, E. R.

1981 Culture Chronology in Central Texas. Bulletin of the Texas Archeological Society 52:65-89.

1995 Distributions of Typed Projectile Points in Texas. Bulletin of the Texas Archeological Society 66:83-173.

Skelton, D. W.

1977 Archeological Investigations at the Fayette Power Project, Fayette County, Texas. Research Report 60. Texas Archeological Survey, The University of Texas at Austin.

Sollberger, J. B., and T. R. Hester

1972 The Strohacker Site: A Review of Pre-Archaic Manifestations in Texas. Plains Anthropologist 17(58):326-344. 
Story, D. A.

1985 Adaptive Strategies of Archaic Cultures of the West Gulf Coastal Plain. In Prehistoric Food Production in North America, edited by R. I. Ford, pp. 19-56. Anthropological Papers No. 75. Museum of Anthropology, University of Michigan, Ann Arbor.

Tankersley, K. B., and B. L. Isaac

1990 Early Paleoindian Economies of North America. JAI Press, Greenwich, Connecticut.

Taylor, A. J., and C. L. Highley

1995 Archaeological Investigations at the Loma Sandia Site (41LK28): A Prehistoric Campsite in Live Oak County, Texas, 2 volumes. Studies in Archeology No. 20. Texas Archeological Research Laboratory, The University of Texas at Austin.

Texas Historical Commission (THC)

2004 Texas Archeological Sites Atlas. <http://pedernales.thc.state.tx.us/> Accessed January 2004.

Tomka, S. A., T. K. Perttula, and R. J. Hard

1997 Archaeology of the Rio Grande and Central Coastal Plains, Texas: A Planning Document. Archaeological Survey Report, No. 266 (Draft). Manuscript on file Center for Archaeological Research, The University of Texas at San Antonio.

Vierra, B. J.

1998 41MV120: A Stratified Late Archaic Site in Maverick County, Texas. Archaeological Survey Report, No. 251. Center for Archaeological Research, The University of Texas at San Antonio; Archeology Studies Program, Report No. 7, Environmental Affairs Division, Texas Department of Transportation, Austin. 
